\title{
PROKARYOTIC COMMUNITIES OF ACIDIC PEATLANDS FROM THE SOUTHERN BRAZILIAN ATLANTIC FOREST
}

\section{R. M. Etto ${ }^{1}$, L. M. Cruz $^{1}$, E. C. Jesus ${ }^{2}$, C. W. Galvão ${ }^{3}$, F. Galvão ${ }^{4}$, E. M. Souza ${ }^{1}$, F. O. Pedrosa ${ }^{1}$, M. B. R. Steffens ${ }^{1 *}$}

${ }^{1}$ Departamento de Bioquímica e Biologia Molecular, Universidade Federal do Paraná, Curitiba, PR, Brasil; ${ }^{2}$ Empresa Brasileira de Pesquisa Agropecuária - Agrobiologia, Seropédica, RJ, Brasil; ${ }^{3}$ Departamento de Biologia Estrutural, Molecular e Genética, Universidade Estadual de Ponta Grossa, Ponta Grossa, PR, Brasil; ${ }^{4}$ Departamento de Ciências Florestais, Universidade Federal do Paraná, Curitiba, PR, Brasil.

Submitted: July 05, 2011; Approved: June 07, 2012.

\begin{abstract}
The acidic peatlands of southern Brazil are ecosystems essential for the maintenance of the Atlantic Forest, one of the 25 hot-spots of biodiversity in the world. In this work, we investigated the composition of prokaryotic communities in four histosols of three acidic peatland regions by constructing small-subunit (SSU) rRNA gene libraries and sequencing. SSU $r R N A$ gene sequence analysis showed the prevalence of Acidobacteria (38.8\%) and Proteobacteria (27.4\%) of the Bacteria domain and Miscellaneous (58\%) and Terrestrial (24\%) groups of Crenarchaeota of the Archaea domain. As observed in other ecosystems, archaeal communities showed lower richness than bacterial communities. We also found a limited number of Euryarchaeota and of known methanotrophic bacteria in the clone libraries.
\end{abstract}

Key words: acidic peatland, prokaryotic communities, SSU rRNA gene, microbial ecology

\section{INTRODUCTION}

Peatlands are ecosystems with high quantity of organic matter due to high water table levels and low temperatures. In the water-saturated layer, the lack of oxygen significantly retards degradation of organic matter, causing plant residues to accumulate as peat. Worldwide, it is estimated that an area of about 400 million ha is covered with peatland, equivalent to 3 $\%$ of the Earth's surface. Most of this area, about 350 million ha, is in the northern hemisphere, harbouring over one-third of the global reserves of soil organic carbon (44). In Brazil, it is estimated that these environment cover approximately 611,883 ha, i.e., around $0.07 \%$ of the national territory (55).

The acidic peatlands of the Paraná state in southern Brazil are contained within the high-altitude grasslands that cover $28,000 \mathrm{~km}^{2}$ of the state. This ecosystem contains herbaceous and bryophytes species and the soils are covered by Sphagnum mosses, the dominant component of the peat bog vegetation (15). This ecosystem belongs to the Brazilian Atlantic Forest and is essential for the maintenance of the biome, which is one of the 25 biodiversity hot-spot in the world (38). Occurring in altitudes higher than 1,000 meters above sea level, these 
Sphagnum peat bogs are large reservoirs of carbon which filter and regulate the water flow of the main hydrographic basins of southern Brazil (Curcio et al., unpublished data).

Sphagnum peat bogs are one of the oldest known landscape type in Brazil (3) and their unique environment for many plants and animals are also an extreme habitat for microorganisms due to their high acidity ( $\mathrm{pH} 3.0-5.0)$, low temperature and low concentration of mineral nutrients (43). Due to the environmental and ecological significance of Sphagnum peat bogs in the global carbon budget and in the emission of methane, their microbial communities are of considerable interest. Up to now there is no record of microbiological studies of Sphagnum peat bogs in southern Brazil. In this study, we have used culture-independent $S S U$ $r R N A$ gene sequencing approach to determine the composition of the archaeal and bacterial communities in three acidic peatland regions from the southern Brazilian Atlantic Forest.

\section{MATERIALS AND METHODS}

\section{Localization and site description}

Histosols were collected in February 2008 from three different physiographic units from sites where the water table was at the peat surface level. In the Serra do Mar $\left(25^{\circ} 53.5^{\prime} \mathrm{S}\right.$; $\left.48^{\circ} 57.5^{\prime} \mathrm{W}\right)$, the samples were collected from a depth of $20 \mathrm{~cm}$ below of the water table (SM20); in the Second Plateau $\left(25^{\circ}\right.$ $16.4^{\prime} \mathrm{S}$; $\left.49^{\circ} 49.5^{\prime} \mathrm{W}\right)$ from depths 20 (CG20) and $50 \mathrm{~cm}$ (CG50) below the water table and in the Third Plateau $\left(26^{\circ} 34.4^{\prime} \mathrm{S} ; 51^{\circ}\right.$ $41.7^{\prime} \mathrm{W}$ ) from $20 \mathrm{~cm}$ below the water table (PA20). The three chosen areas are preserved Sphagnum peat bogs from the southern Brazilian Atlantic Forest. Differences in the landscape of these ecosystems are related to the use of their surrounding areas. Adjacent to the Serra do Mar peatland is the upper mountain Atlantic Rainforest; to the Second Plateau, are pasture fields and to the Third Plateau, agricultural crops. In these areas the climate is temperate and humid without major dry periods. The annual precipitation average is between 1,400 and 2,200 $\mathrm{mm}$ and the annual temperature ranges mainly between 12 and $18^{\circ} \mathrm{C}$ (3). The acidic peatland histosol is dominantly covered with Sphagnum moss, containing species of the Poaceae and Cyperaceae and small shrubs of Asteraceae, Melastomataceae, Ericaceae, Eriocaulaceae and Verbenaceae families. Ten histosol samples were randomly collected from an area of approximately $400 \mathrm{~m}^{2}(20 \mathrm{~m} \times 20 \mathrm{~m})$ and mixed into a composite sample of each site. From each sample, approximately 100 grams of soil were transferred to Falcon tubes and kept on ice for DNA extraction. The rest of the samples was collected in sealed plastic bags, stored at room temperature and sent for chemical analysis to the Department of Soil and Agricultural Engineering of the Federal University of Paraná (UFPR, Brazil) (Table 1).

\section{Histosol DNA extraction and quantification}

One gram of histosol was used for nucleic acids extraction with the "Ultraclean Soil DNA kit" (MO BIO Laboratories) according to the manufacturer's instructions. The DNA integrity was determined by electrophoresis in $1 \mathrm{X}$ TAE- $0.8 \%$ agarose gels and stained with ethidium bromide $(0.5 \mu \mathrm{g} / \mathrm{mL})$.

\section{PCR amplification}

Bacterial and archaeal SSU $r R N A$ genes were amplified from $50 \mathrm{ng}$ of soil DNA by PCR. Prior to the PCR, samples were incubated with $0.6 \mu \mathrm{g}$ of BSA per ng of DNA in a total volume of $11 \mu \mathrm{l}$ for $45 \mathrm{~min}$ at $37^{\circ} \mathrm{C}$ to scavenge PCR inhibiting substances. After chilling on ice, in a PCR final volume of 50 $\mu \mathrm{l}$, the following reagents were added: $1 \times$ PCR buffer (Invitrogen), $0.2 \mu \mathrm{M}$ of each primer, $2 \mathrm{mM} \mathrm{MgCl}_{2}, 0.2 \mathrm{mM}$ dNTP (Invitrogen), $0.3 \mu \mathrm{g}$ BSA and $1 \mathrm{U}$ Taq DNA polymerase (Invitrogen). Amplifications were performed in a Mastercycler gradient thermocycler (Eppendorf). The primers 27F (5'AGAG TTTGATCMTGGCTCAG) and 1492R (5'GGTTACCTTGTT ACGACTT) (51) were used for the amplification of bacterial SSU $r R N A$ and the primers 21F (5' TTCYGGTTGATCCYGC CRGA) and 958R (5', YCCGGCGTTGANTCCAATT) (37) 
were used for the amplification of the archaeal SSU $r R N A$ gene. The following conditions were used for PCR with both primer sets: $3 \mathrm{~min}$ at $95{ }^{\circ} \mathrm{C} ; 25$ cycles of $45 \mathrm{~s}$ at $95^{\circ} \mathrm{C}, 45 \mathrm{~s}$ at $55^{\circ} \mathrm{C}$ and $1.5 \mathrm{~min}$ at $72^{\circ} \mathrm{C}$; and a final extension for $10 \mathrm{~min}$ at $72^{\circ} \mathrm{C}$. The quantity and quality of the amplification products were verified by gel electrophoresis in $1 \mathrm{X}$ TAE-1\% agarose and analysed with the LabWorks ${ }^{\mathrm{TM}} 4.0$ Imaging Analysis and Acquisition software (UVP Inc.).

\section{$S S U r R N A$ gene cloning and sequencing}

Approximately $75 \mathrm{ng}$ of $S S U$ rRNA gene amplicons were ligated to $50 \mathrm{ng}$ of pGEM-T easy vector (Promega), according to the manufacturer's instructions. The ligation product was transformed into Escherichia coli DH5 $\alpha$ competent cells. Eight clone libraries were constructed: four contained bacterial $S S U$ rRNA gene inserts (SM20Bac, CG20Bac, CG50Bac and PA20Bac) and four contained archaeal SSU $r R N A$ sequences (SM20Arq, CG20Arq, CG50Arq and PA20Arq). Plasmids were extracted by the alkaline lysis method in 96 well plates. Sequencing was performed using $250 \mathrm{ng}$ of plasmid DNA, 3.25 pmol of primer (27F for Bacteria and 21F/958R for Archaea), $3 \mu \mathrm{L}$ of ET terminator mix (GE Healthcare) and ultrapure $\mathrm{H}_{2} \mathrm{O}$ to a final volume of $7.5 \mu \mathrm{L}$, in 1 cycle of $1 \mathrm{~min}$ at $95^{\circ} \mathrm{C} ; 35$ cycles of $20 \mathrm{~s}$ at $94^{\circ} \mathrm{C}$ and $2 \mathrm{~min}$ at $62^{\circ} \mathrm{C}$. Products were precipitated with three volumes of absolute ethanol, washed with $70 \%$ ethanol, dried and dissolved in deionized formamide. Sequencing was performed using a MegaBACE 1000 sequencer (GE Healthcare). Reads were trimmed for the removal of low quality bases using the Phred program (19). For the Archaea domain, the Phrap program (26) was used to assemble the reads from both primers used for sequencing into the SSU rRNA partial gene sequence and the Consed program was used to view and edit the sequence assembly (25). The obtained SSU rRNA gene sequences were deposited in the GenBank database under the accession no. HQ613951HQ614492 (archaeal sequences) and HQ614493-HQ615057 (bacterial sequences).

\section{Sequence analyses}

SSU $r R N A$ gene sequences were aligned and analyzed with RDP tools (release 10) (14) and with the Mothur program (47). The chimeras, if detected, were removed with Bellerophon using the Huber-Hugenholtz correction, Chimera Check or Pintail using as template the Greengenes database for Bacteria and Silva database for Archaea. Alignments were edited manually or with GBlocks (9). Nucleotide substitution models were selected by using PAUP* version $4.0 \mathrm{~b} 10$ (52) and ModelTest (41). Sequences were clustered into OTU (Operational Taxonomic Unit - identity $\geq 97 \%$ ). Phylogenies were constructed with the neighbor-joining algorithm by using the program MEGA version 4.0 (53). The similarity in the composition of the clone libraries was examined by two methods: J-LibShuff (46) and R (42) programs, using an abundance matrix of OTUs. Renyi diversity profiles to rank prokaryotic communities according to diversity (33). The chisquare test was used to verify differences in the frequencies of the phyla in samples.

\section{RESULTS AND DISCUSSION}

\section{Bacterial and archaeal communities from acidic peatlands}

In this work we identified the major bacterial and archaeal groups present in acidic peatland from the southern Brazilian Atlantic Forest by SSU rRNA gene sequencing from the Serra do Mar (SM20), the Second Plateau (CG20 and CG50) and the Third Plateau (PA20). 565 sequences of the bacterial SSU $r R N A \mathrm{~V} 2-\mathrm{V} 3$ region with an average length of $450 \mathrm{pb}$ were recovered. The majority of the sequences belong to the Acidobacteria (33.8\%) and Proteobacteria (26.2\%) phyla (Fig. 1A). These two groups were the most numerous found in both forest soil and in Sphagnum peat bogs $(17,29)$. Four bacterial clones of Proteobacteria were related to methanotrophs (Methylococcaceae and Methylocystaceae families), with only one sequence showing $96 \%$ similarity with the genus Methylocystis. From the three studied areas, only the Third 
Plateau (Fig. 1A, PA20Bac) contained a higher number of representatives of Proteobacteria than Acidobacteria. Since the Proteobacteria/Acidobacteria ratio has been correlated to the soil trophic status $(27,49)$, PA20 probably diverged from the other samples in this characteristic because of the anthropic interference caused by agriculture in the surrounding areas. The peatland of the Second Plateau, showed the highest content of organic matter (Table 1) and the highest abundance of Acidobacteria (Fig. 1A). The relationship between the prevalence of Acidobacteria and soil composition can be explained in part by their particular metabolism, since the acidophillic Acidobacteria are oligotrophs, characterized by slow growth rates and metabolism of more refractory carbon substrates, a characteristic of peat soils (18).

The composition of the dominant groups in the Second Plateau site changed with depth of sample collection, and the Ktedonobacter genus (Bacteria_incertae_sedis phylum), which includes spore-forming, gram-positive filamentous bacteria (10), was the second most abundant group at the $50 \mathrm{~cm}$ depth (Fig. 1A). An increase in the abundance of gram-positive bacteria with depth in a soil profile was also observed by Fierer et al. (22). However, cluster analysis by Bray-Curtis distances (Fig. 2B) and $\int$-Libshuff analysis $(P>0.05)$ revealed that the samples from depths of 20 and $50 \mathrm{~cm}$ of the same peatland (CG20Bac and CG50Bac libraries) are the most similar communities. These soil samples had very similar chemical composition (Table 1) which probably explains the high similarity of the two libraries.

Phylogenetic analysis of dominant groups showed that representatives of the Acidobacteria (Gp1,Gp2 and Gp3) and of the classes of Proteobacteria (Alpha, Beta, Gamma and Delta) were present in all samples, contributing to the high similarity of the libraries (Fig. S1 and S2). The taxa responsible for the observed differences belonged mainly to the least abundant phyla: Firmicutes, Verrucomicrobia, Bacteria incertae_sedis, Bacteroidetes, Chloroflexi and Actinobacteria (Fig. 1A).
One study of a Sphagnum peat bog in Western Siberia showed that Verrucomicrobia was the third most abundant phylum (17) and other studies based on SSU rRNA sequencing suggested that Verrucomicrobia represent one of the most dominant phyla of soil environments $(29,32)$. They typically represent between $2 \%$ and $8 \%$ of the total bacterial community, with the highest densities observed in the rhizosphere (32). However, no representative of this phylum was found in the peatland of Serra do Mar (SM20Bac library) (Fig. 1A). This was the only peatland area surrounded by the Atlantic Rainforest. A recent study of soil of the Atlantic Rainforest also found no representatives of this phylum (20).

Distribution analysis showed a high percentage of unique OTUs in all four bacterial libraries varying from 58 to $80 \%$ (Table 1). Only two OTUs belonging to the Gp1 and Gp2 genera were present in all libraries. Representatives of the class Deltaproteobacteria were also present in all pairwise comparisons (Table 2).

A total of 542 sequences of archaeal SSU rRNA spanning V2-V5 region with an average length of 800 bp were also obtained. In contrast to that observed for peatlands of the northern hemisphere $(8,30)$, methanogens do not appear to dominate archaeal communities of the southern Brazilian Atlantic Forest peatlands. In these ecosystems $90 \%$ of the sequences belonged to the Crenarchaeota phylum, and only $9 \%$ were from methanogens, which belonged to the Euryarchaeota phylum (Fig. 1B).

Two groups were dominant within the phylum Crenarchaeota: Miscellaneous Crenarchaeotic Group (MCG, 58\%) and Terrestrial Group (TG, 24\%) (Fig. 1B). MCG has a wide habitat range, which includes terrestrial and marine, hot, cold, surface or subsurface environments (54). The presence of MCG in the SM20, CG20, CG50 and PA20 peatlands confirms the wide distribution of this group. The TG contains crenarchaeotal sequences that were mainly retrieved from soil samples and the rhizosphere $(40,48)$. The wide distribution of TG in soil indicates that it is one of the most globally 
distributed archaeal group in terrestrial habitats. However, the ecophysiology and function of Crenarchaeota remain unclear due to the lack of cultured isolates.

As observed for Bacteria, the archaeal communities detected in samples from different depths of the same peatland (CG20Arq and CG50Arq libraries) were the most similar, but in contrast to the bacterial libraries, the SM20Arq and PA20Arq archaeal libraries exhibited the highest similarity (Fig. 2C). Phylogenetic analysis of crenarchaeotal groups showed that the representatives of MCG were responsible for the high similarity of the SM20Arq and PA20Arq libraries (Fig. S3). The four libraries shared two OTUs of MCG and TG (Table 2).

Soil depth seemed to influence the distribution of the archaeal taxa. The archaeal community from the sample collected at $50 \mathrm{~cm}$ showed a lower percentage of unshared OTUs $(40.8 \%)$ than that from $20 \mathrm{~cm}(66.7 \%$ of unique OTUs $)$ (Table 1).

In this study, the SSU rRNA gene sequence of the following methanogens were found: Rice Cluster-I (RC-I), Rice Cluster-II (RC-II), Methanosaeta, Gulf of Mexico Arc I group (GOM Arc I), Methanomicrobiaceae, Candidatus Methanoregula and Methanocella (Fig. 3). Parwise comparisons between libraries indicated that SM20Arq and PA20Arq shared one OTU of the Methanomicrobiaceae family and one of the Rice_Cluster II group; CG20Arq and PA20Arq shared one OTU of the GOM_ArcI group; and CG50Arq and PA20Arq shared one OTU of the Rice_Cluster II (Table 2). No methanogenic OTU was shared between the libraries CG20Arq and CG50Arq or SM20Arq and CG20Arq.

The RC-I and RC-II groups have been found in different ecosystems with active methanogenesis, such as acidic peatlands and rice paddies $(8,12,24)$. Members of the RC-I group, found only in the Second Plateau (CG20Arq and CG50Arq libraries) (Fig. 3), are characterized as hydrogenotrophic methanogens and have been found to produce methane near rice roots (45) by using the accumulated
$\mathrm{H}_{2}$, generated from the fermentation of secreted photosynthates (16). This group is particularly abundant in rice paddies, where it can make up 20 to $50 \%$ of the total number of methanogens (34). However it represented only $4 \%$ of the methanogens in our area of study, which is similar to other peatlands (7). RC-II was the most abundant methanogen group with representatives in the PA20Arq, SM20Arq and CG50Arq libraries (Fig. 3). Members of RC-II seem to tolerate a broad range of $\mathrm{pH}$ values, since sequences have been retrieved from acidic as well as neutral sites $(2,12,31)$.

Sequences clustering with Methanoregula spp. were present in libraries SM20Arq and PA20Arq (Fig. 3). These are likely to represent hydrogenotrophic and/or formatotrophic methanogens, since members of this group are known to utilize $\mathrm{H}_{2} / \mathrm{CO}_{2}$ (4) or $\mathrm{H}_{2} / \mathrm{CO}_{2}$ or formate (57). This group is abundant in other oligotrophic peatlands $(23,50)$, and has been shown to grow in low-nutrient and low-ionic-strength medium and to be highly sensitive to oxygen (5), suggesting its adaptation to extreme anaerobic environments. Other sequences of the hydrogenotrophic orders Methanomicrobiales and Methanocellales were also found.

Taxa of the group GOM Arc I (36) present in PA20Arq, CG20Arq and CG50Arq (Fig. 3) were closest to uncultured archaea of sediment and peatland $(6,7,39)$. Although this group is phylogenetically close to the group ANME-2 (Archaeal ANaerobic MEthane oxidizers, 36), there is no evidence of methane-oxidation by members of the GOM arc I.

The sequence related to acetoclastic Methanosaeta was found only in PA20Arq and comprised 11\% of the total methanogens (Fig. 3). The absence of other acetotrophs belonging to the family Methanosarcinaceae in this peatland suggests a low concentration of acetate in this bog, since in ecosystems where acetate concentrations are high Methanosaeta are outcompeted by Methanosarcina (13, 21, 56).

In agreement with Aller and Kemp (1), who compared bacterial and archaeal richness of several environments and 
observed that in the majority of the studied ecosystems the bacterial richness was higher than archaeal richness, the southern Brazil acidic peatlands also had a higher richness of Bacteria than Archaea (Fig. 4). Besides, the Third Plateau (PA20) peatland showed higher procariotic diversity among the samples studied (Fig. 2A).

In conclusion, the predominance of hydrogenotrophic methanogens $(89 \%$ of the methanogens) suggests that the main production of $\mathrm{CH}_{4}$ occurs through the $\mathrm{H}_{2}-\mathrm{CO}_{2}$ pathway. This result is consistent with other studies, which showed that hydrogenotrophy is the dominant reaction in bogs $(11,23,28$, 35). Furthermore, this is also the first study to reveal the prokaryotic diversity in the southern Brazilian Atlantic Forest peatlands, showing a higher richness of Bacteria than Archaea.
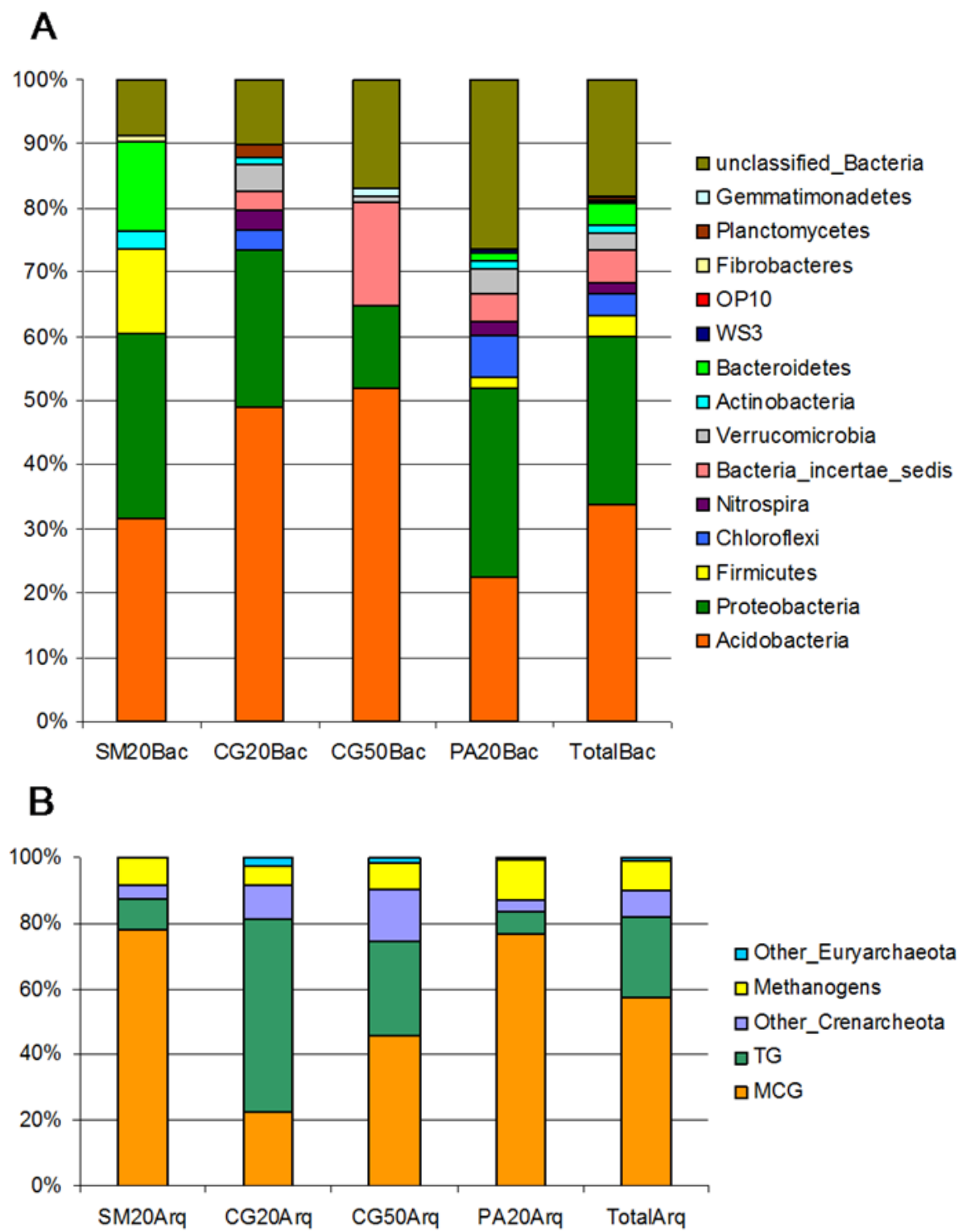

Figure 1. Taxonomic composition of the prokaryotic communities. Sequences of (A) Bacteria and (B) Archaea domains were compared with Ribosomal Database Project II and Silva Database respectively. Significant differences with respect to phyla frequencies per sample were observed in a Chi-square test. 


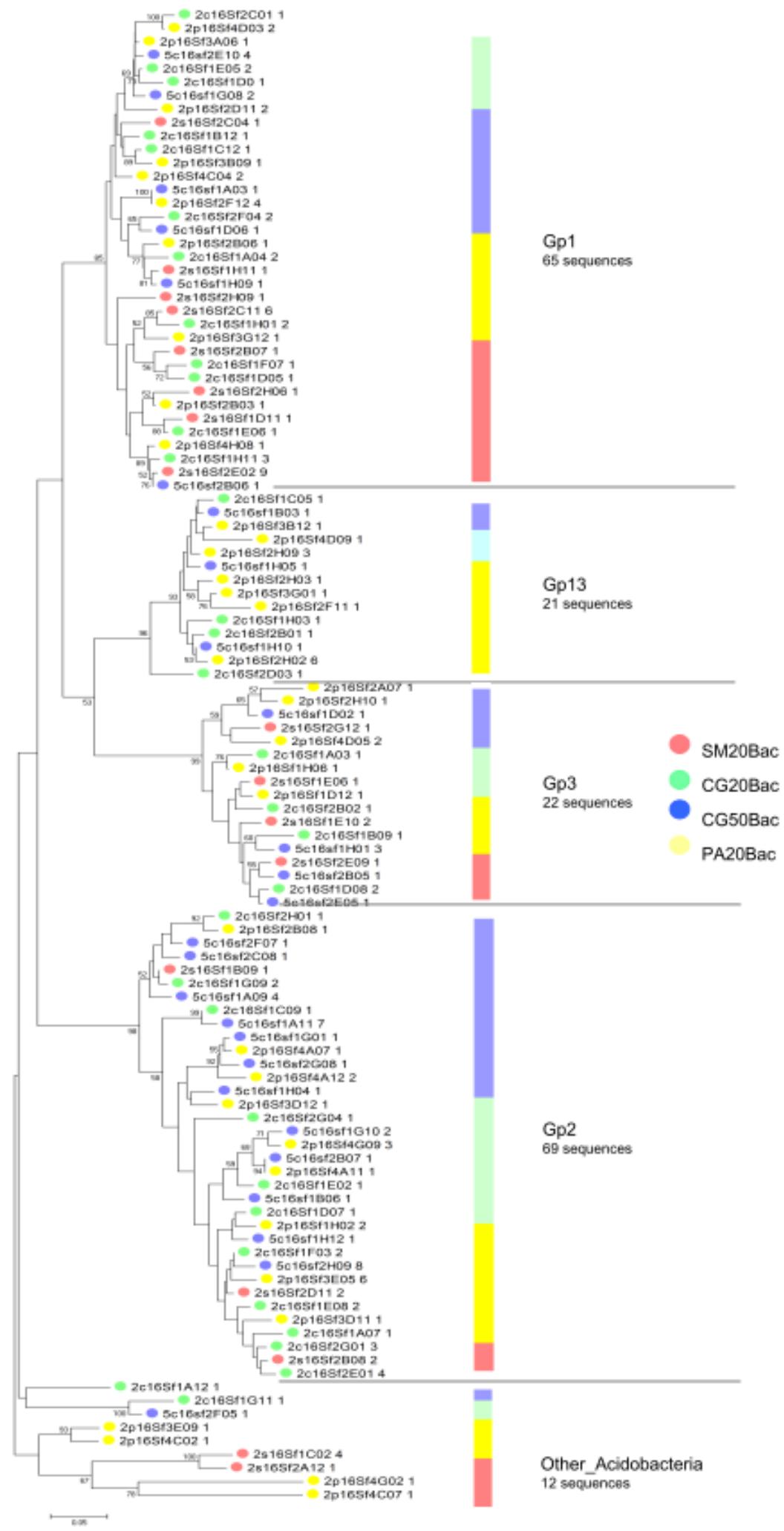

Figure S1. Phylogenetic relationships among acidobacterial OTUs and their areas of origin. Each circle represents a different OTU and the number after its ID indicates the number of sequences that compose this OTU. Each colour represents a different area as shown in the picture. The bar indicates the proportion of sequences of each genus. Phylogenies were estimated by neighbor joining with the TrN model and $\gamma$ correction $(\alpha=0.4882)$. Tree is unrooted. The scale bar represents changes per nucleotide. 


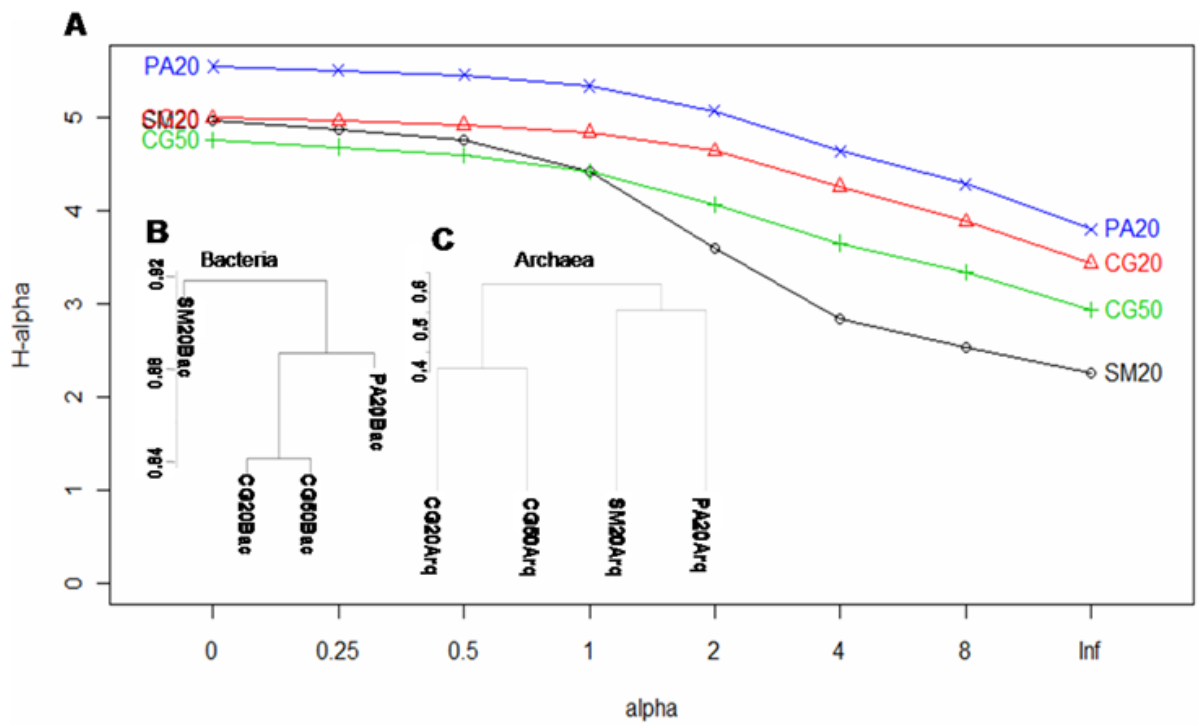

Figure 2. Renyi diversity profiles and similarity dendograms based in OTU. (A) Comparison of the Renyi diversity profiles of the peatland prokaryote communities. The profile values for alpha $=0,1,2$ and infinity indicate the species richness, Shannon diversity index, logarithm of the reciprocal Simpson diversity index and Berger Parker diversity index, respectively. If the profile for one sample was consistently higher than the profile for another sample, the sample with the higher profile was considered more diverse. When curves for two communities intersect, this means that they cannot be ranked. (B) and (C) show an average linkage clustering dendrogram based on the Bray-Curtis distances among bacterial and archaeal communities, respectively.

Table 1. Distribution of OTUs and soil chemical attributes of the samples

\begin{tabular}{|c|c|c|c|c|c|c|c|}
\hline \multirow{2}{*}{ Sample } & \multicolumn{2}{|c|}{ Bacterial OTU } & \multicolumn{2}{|c|}{ Archaeal OTU } & \multirow{2}{*}{$\underset{\mathrm{CaCl}}{\mathrm{pH}}$} & \multirow{2}{*}{$\begin{array}{c}\mathbf{g} / \mathbf{k g} \\
\mathrm{C}\end{array}$} & \multirow{2}{*}{$\begin{array}{l}\text { g/kg } \\
\text { OM }\end{array}$} \\
\hline & Unshared & Shared & Unshared & Shared & & & \\
\hline SM20 & $69(80.2 \%)$ & $17(19.8 \%)$ & $43(74.1 \%)$ & $15(25.9 \%)$ & 3.20 & 256.11 & 441.54 \\
\hline CG20 & $48(60.7 \%)$ & $31(39.3 \%)$ & $46(66.7 \%)$ & $23(33.3 \%)$ & 3.80 & 265.81 & 458.50 \\
\hline CG50 & $37(58.7 \%)$ & $26(41.3 \%)$ & $22(40.8 \%)$ & $32(59.2 \%)$ & 3.80 & 267.01 & 460.10 \\
\hline PA20 & $136(80 \%)$ & $34(20 \%)$ & $61(69.3 \%)$ & $27(30.7 \%)$ & 4.00 & 172.57 & 297.51 \\
\hline
\end{tabular}

$\mathrm{C}=$ carbon; $\mathrm{OM}=$ organic matter.

Table 2. Prokaryotic OTUs shared among the libraries. The sequences that compose the bacterial and archaeal OTUs were compared with Ribosomal Database Project II and Silva database respectively. The number of OTUs that compose each taxon are shown in parentheses.

\begin{tabular}{|c|c|c|}
\hline Libraries & Bacteria shared & Archaea shared \\
\hline SM20 CG20 & $\begin{array}{l}\text { Gpl (3), Gp2 (4), Gammaproteobacteria (1), Deltaproteobacteria (1), Proteobacteria (3) and } \\
\text { Bacteria (1). }\end{array}$ & Terrestrial Group (3) and MCG (4). \\
\hline SM20 CG50 & Gp3 (1), Gp2 (2), Gp1 (2) and Deltaproteobacteria (1). & $\begin{array}{l}\text { Terrestrial Group (3), Rice_ClusterII (2) and } \\
\text { MCG (5). }\end{array}$ \\
\hline SM20 PA20 & Deltaproteobacteria (1), Gp3 (1), Gp2 (2), Gpl (2) and Bacteria (2). & $\begin{array}{l}\text { Terrestrial Group (2), Methanomicrobiaceae } \\
\text { (1), Rice_ClusterII (1) and MCG (6). }\end{array}$ \\
\hline CG20 CG50 & $\begin{array}{l}\text { Ktedonobacter (1), Betaproteobacteria (1), Deltaproteobacteria (2), Gp13 (1), Gp1 (3), Gp2 (4) } \\
\text { and Bacteria (1). }\end{array}$ & $\begin{array}{l}\text { MCG (7), Thermoprotei (1) and Terrestrial } \\
\text { Group (10). }\end{array}$ \\
\hline CG20 PA20 & $\begin{array}{l}\text { Anaerolineales (1), Nitrospira (1), Gp3 (1), Gp2 (2), Gp1 (4), Subdivision3_genera_incertae_sedis } \\
\text { (1), Betaproteobacteria (1), Deltaproteobacteria (2), Proteobacteria (2) and Bacteria (3). }\end{array}$ & $\begin{array}{l}\text { Terrestrial Group (1), GOM_ArcI (1) and } \\
\text { MCG (10). }\end{array}$ \\
\hline PA20 CG50 & $\begin{array}{l}\text { Subdivision3_genera_incertae_sedis (1), Ktedonobacter (1), Desulfuromonadales (1), } \\
\text { Deltaproteobacteria (1), Gp3 (1),Gp13(1),Gp1 (3),Gp2 (5) and Bacteria (2). }\end{array}$ & $\begin{array}{l}\text { Terrestrial Group (3), Rice_ClusterII (1), } \\
\text { Thermopotei (1) and MCG (13). }\end{array}$ \\
\hline SM20 CG20 CG50 & Gp2 (2), Gpl (1) and Deltaproteobacteria (1). & Terrestrial Group (3) and MCG (3). \\
\hline SM20 CG20 PA20 & Proteobacteria (1), Gp2 (1) and $G p 1$ (1) & Terrestrial Group (1) and MCG (4) \\
\hline SM20 CG50 PA20 & $G p 2(1)$ and $G p l(1)$. & $\begin{array}{l}\text { Terrestrial Group (1) Rice_ClusterII (1) and } \\
\text { MCG (3). }\end{array}$ \\
\hline CG20 CG50 PA20 & Deltaproteobacteria (1), Gp2 (2) and $G p 1$ (2). & Terrestrial Group (1) and MCG (6). \\
\hline SM20 CG20 CG50 PA20 & $G p 2(1)$ and $G p 1(1)$. & MCG (3) and Terrestrial Group (1). \\
\hline
\end{tabular}




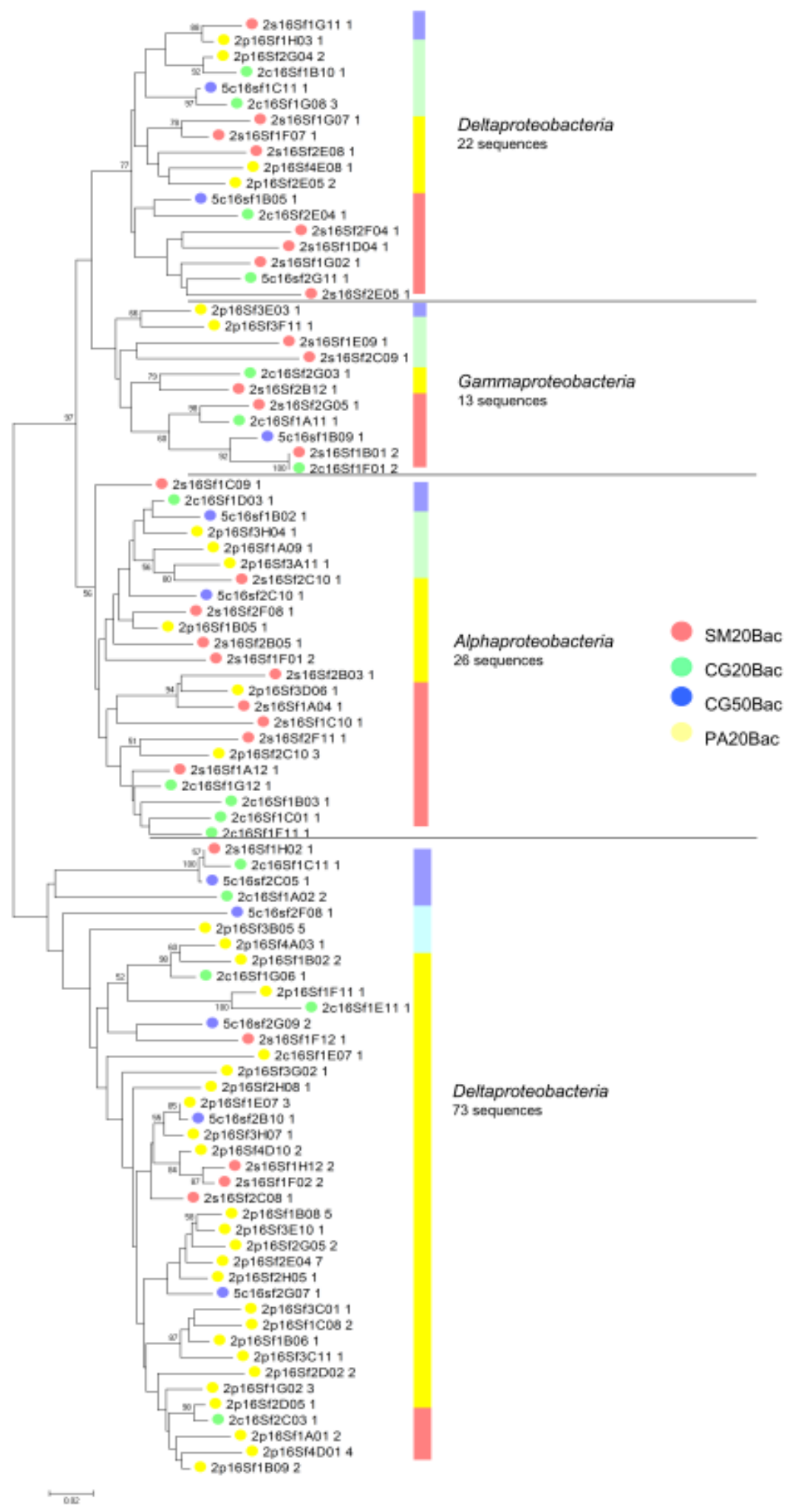

Figure S2. Phylogenetic relationships among proteobacterial OTU and their areas of origin. Each circle represents a different OTU and the number after its ID indicates the number of sequences that compose this OTU. Each colour represents a different area as shown in the picture. The bar indicates the proportion of sequences of each class. Phylogenies were estimated by neighbor joining with the TrN model and $\gamma$ correction $(\alpha=$ 0.6241). The tree is unrooted. The scale bar represents changes per nucleotide. 


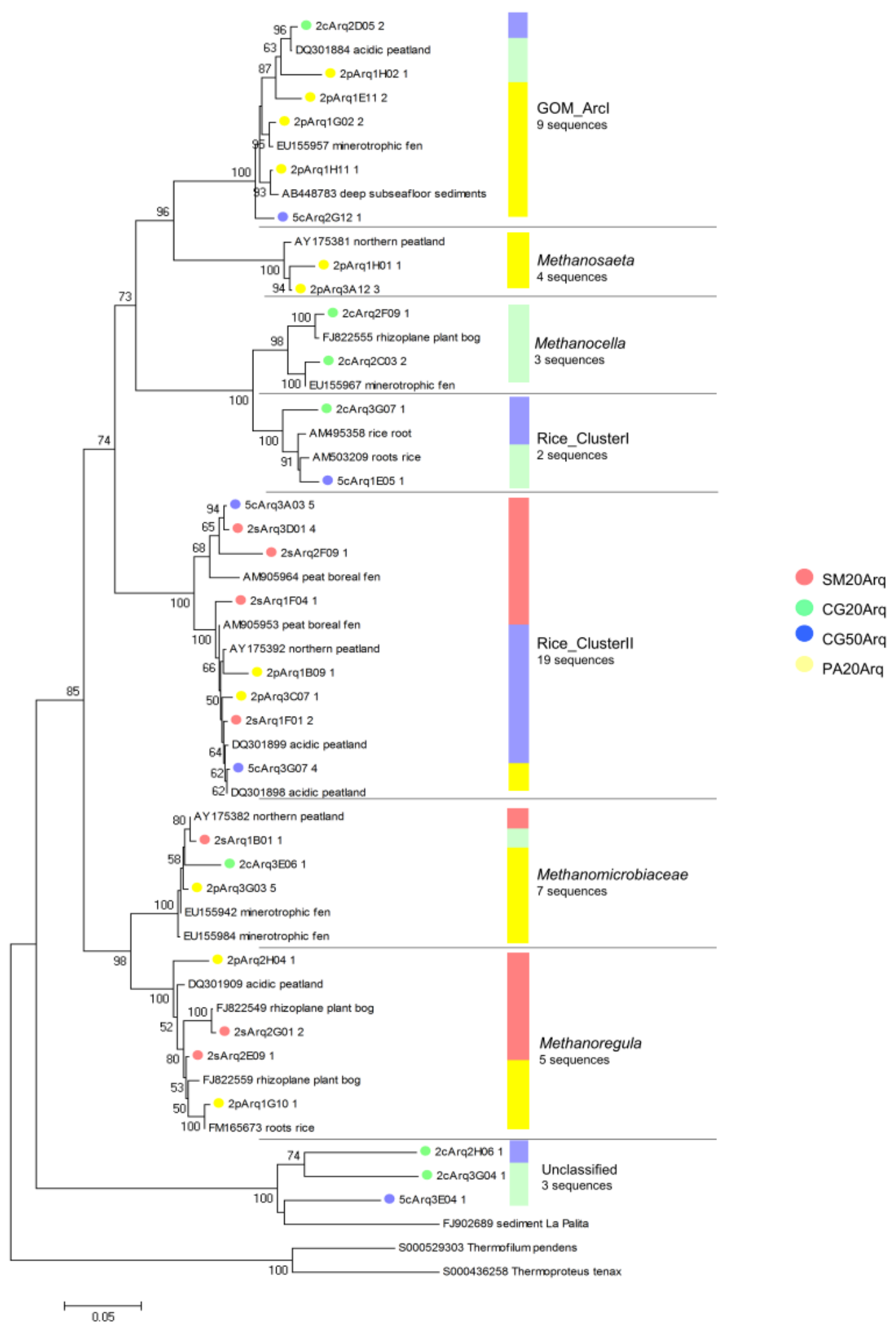

Figure 3. Phylogenetic relationships among methanogenics OTUs and their areas of origin. Each circle represents a different OTU and the number after its ID indicates the number of sequences that compose this OTU. Each colour represents a different area as shown in the picture. The bar indicates the proportion of sequences in each group. Sequences were compared with the NCBI and Silva database for the construction of the tree. Phylogenies were estimated by neighbor joining with the $\operatorname{TrN}$ model and $\gamma$ correction $(\alpha=1.0852)$. The tree was rooted using Thermofilum pendens and Thermoproteus tenax as an outgroup. The scale bar represents changes per nucleotide. 


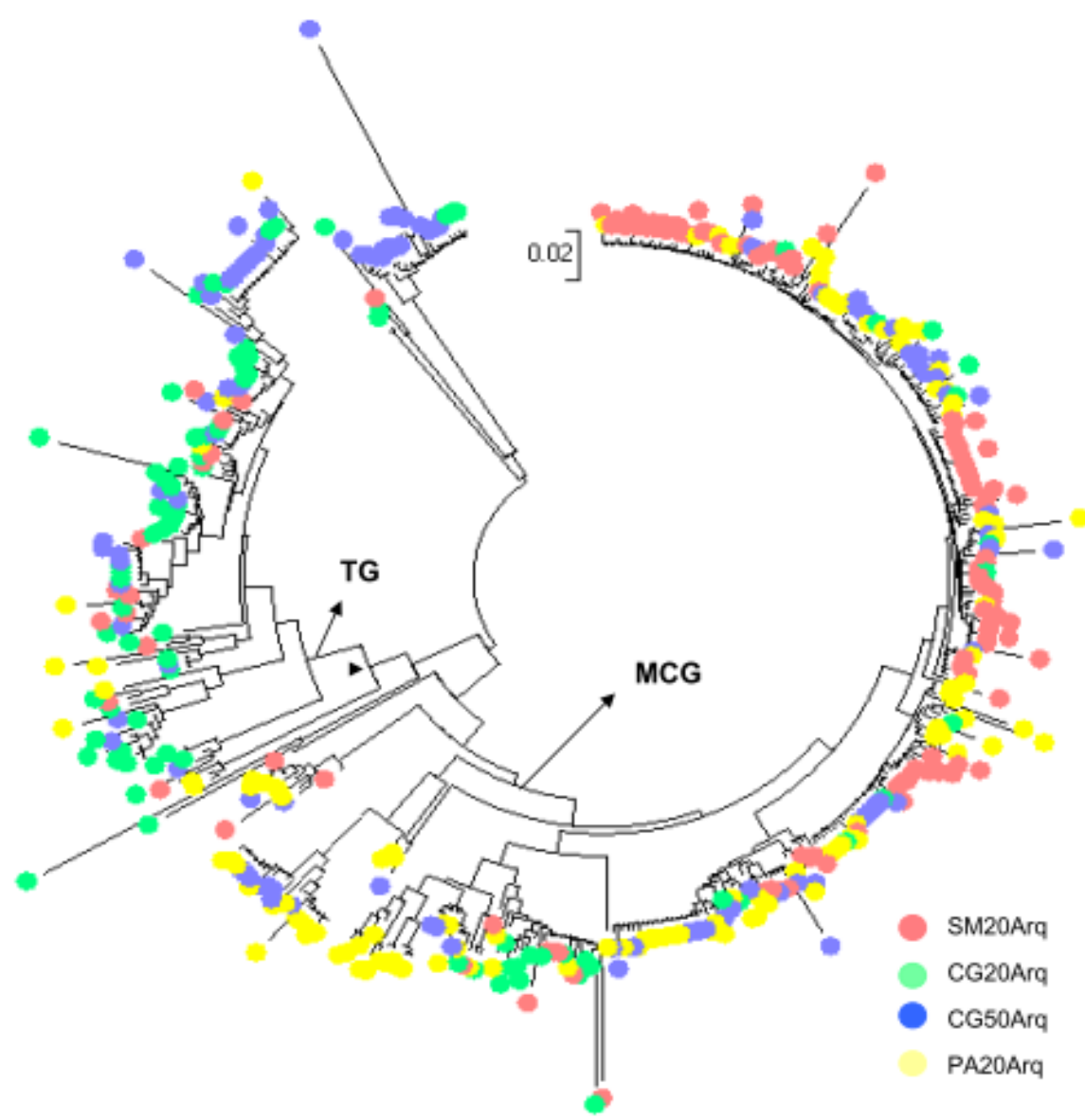

Figure S3. Phylogenetic relationships among crenarcheotal sequences and their origin. Each colour represents a different area as shown in the picture. Sequences were classified using Silva database. Phylogenies were estimated by neighbor joining with the LogDet. Tree is unrooted. The scale bar represents changes per nucleotide. Each symbol represents a different area. Clades of the Terrestrial Group (TG) and Micellaneous Crearchaeota Group (MCG) are indicated on the tree.

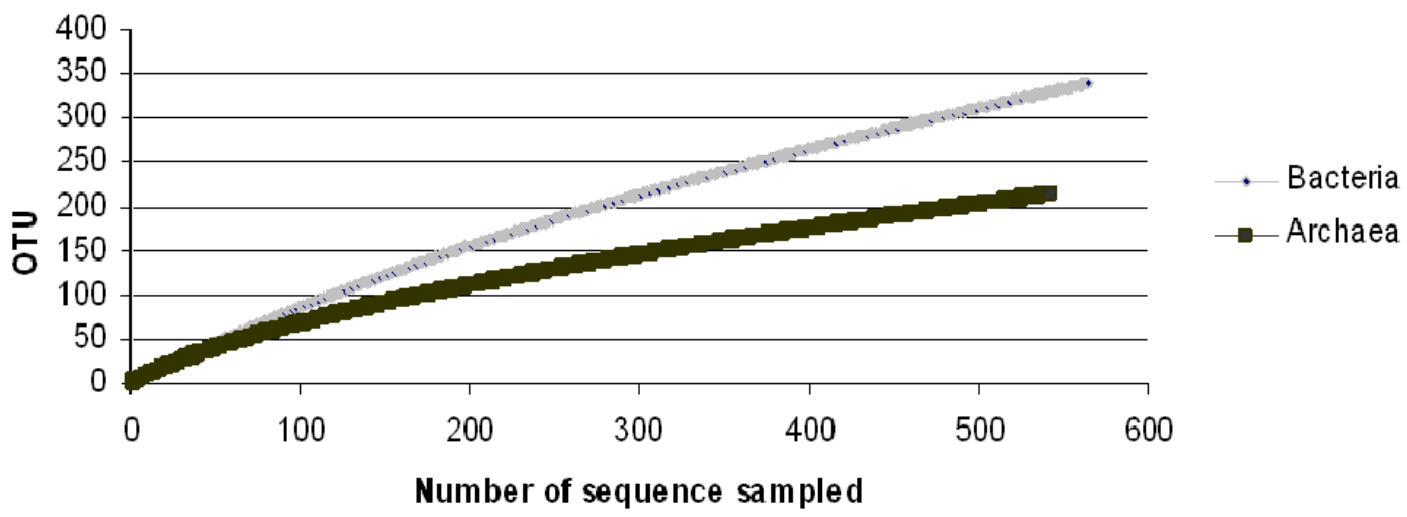

Figure 4. Rarefaction curve analyses of bacterial and archaeal SSU rRNA gene sequences across all sites. Bacterial sequences are represented by light gray diamonds and archaeal by dark gray squares. 


\section{ACKNOWLEDGEMENTS}

We would like to thank the Brazilian Research Council (CNPq), INCT-Biological Nitrogen Fixation and Fundação Araucária of the Paraná State - Brazil for financial support. We thank Julieta Pie, Marilza Doroti Lamour and Roseli Prado for technical support, Valter Baura from sequencing reactions, Dr. Gustavo Ribas Curcio and Msc. Marcos Fernando Gluck Rachwal for help with data collection and soil physic-chemical analysis and Dr. M. Geoffrey Yates for critical reading of the manuscript.

\section{REFERENCES}

1. Aller, J.Y.; Kemp, P.F. (2008). Are Archaea inherently less diverse than Bacteria in the same environments? FEMS Microbiol. Ecol. 65(1), 7487.

2. Basiliko, N.; Yavitt, J.B.; Dees, P.M.; Merkel, S.M. (2003). Methane Biogeochemistry and Methanogen Communities in Two Northern Peatland Ecosystems, New York State. Geomicrobiol. J. 20(6), 563-577.

3. Behling, H. (2002). South and southeast Brazilian grasslands during Late Quaternary times: a synthesis. Palaeogeogr. Palaeoclimatol. Palaeoecol. 177(2), 19-27.

4. Brauer, S.L.; Cadillo-Quiroz, H.; Ward, R.J.; Yavitt, J.B.; Zinder, S.H. (2011). Methanoregula boonei gen. nov., sp. nov., an acidiphilic methanogen isolated from an acidic peat bog. Int. J. Syst. Evol. Microbiol. 61(1), 45-52.

5. Bräuer, S.L.; Cadillo-Quiroz, H.; Yashiro, E.; Yavitt, J.B.; Zinder, S.H. (2006). Isolation of a novel acidiphilic methanogen from an acidic peat bog. Nature. 442(7099), 192-194.

6. Cadillo-Quiroz, H.; Brauer, S.; Yashiro, E.; Sun C.; Yavitt, J.; Zinder, S. (2006). Vertical profiles of methanogenesis and methanogens in two contrasting acidic peatlands in central New York State, USA. Environ. Microbiol. 8(8), 1428-1440.

7. Cadillo-Quiroz, H.; Yashiro, E.; Yavitt, J.B.; Zinder, S.H. (2008). Characterization of the archaeal community in a minerotrophic fen and terminal restriction fragment length polymorphism-directed isolation of a novel hydrogenotrophic methanogen. Appl. Environ.Microbiol. 74(7), 2059-2068.

8. Cadillo-Quiroz, H.; Yavitt, J.B.; Zinder S.H.; Thies J.E. (2010). Diversity and community structure of Archaea inhabiting the rhizoplane of two contrasting plants from an acidic bog. Microb. Ecol. 59(4), 757767.

9. Castresana, J. (2000). Selection of conserved blocks from multiple alignments for their use in phylogenetic analysis. Mol. Biol. Evol. 17(4), $540-552$.

10. Cavaletti, L.; Monciardini, P.; Bamonte, R.; Schumann, P.; Rohde, M.; Sosio, M.; Donadio, S. (2006). New lineage of filamentous, sporeforming, gram-positive bacteria from soil. Appl. Environ. Microbiol. 72(6), 4360-4369.

11. Chasar, L.S.; Chanton, J.P.; Glaser, P.H.; Siegel, D.I.; Rivers, J.S. (2000). Radiocarbon and stable carbon isotopic evidence for transport and transformation of dissolved organic carbon, dissolved inorganic carbon, and CH4 in a northern Minnesota peatland. Global Biogeochem. Cycles. 14(4), 1095-1108.

12. Chin, K.J.; Lukow, T.; Conrad, R. (1999). Effect of temperature on structure and function of the methanogenic archaeal community in an anoxic rice field soil. Appl. Environ. Microbiol. 65(6), 2341-2349.

13. Chin, K.J.; Lueders, T.; Friedrich, M.W.; Klose, M.; Conrad, R. (2004). Archaeal community structure and pathway of methane formation on rice roots. Microb. Ecol. 47(1), 59-67.

14. Cole, J.R.; Wang, Q.; Cardenas, E.; Fish, J.; Chai, B.; Farris, R.J.; Kulam-Syed-Mohideen, A.S.; McGarrell, D.M.; Marsh, T.; Garrity, G.M.; Tiedje, J.M. (2009). The Ribosomal Database Project: improved alignments and new tools for rRNA analysis. Nucleic Acids Res. 37(Database issue), D141-145.

15. Daniels, R.; Eddy, A. (1985). Handbook of European Sphagna. Institute of Terrestrial Ecology. Abbots Ripton Huntingdon, Cambridgeshire, UK.

16. Dannenberg, S.; Conrad, R. (1999). Effect of rice plants on methane production and rhizospheric metabolism in paddy soil. Biogeochemistry. 45(1), 53-71.

17. Dedysh; S.N.; Pankratov, T.A.; Belova, S.E.; Kulichevskaya I.S.; Liesack W. (2006). Phylogenetic analysis and in situ identification of bacteria community composition in an acidic Sphagnum peat bog. Appl. Environ. Microbiol. 72(3), 2110-2117.

18. Eichorst, S.A.; Breznak, J.A.; Schmidt T.M. (2007). Isolation and characterization of soil bacteria that define Terriglobus gen. nov., in the phylum Acidobacteria. Appl. Environ. Microbiol. 73(8), 2708-2717.

19. Ewing, B.; Hillier, L.; Wendl, M.C.; Green, P. (1998). Base-calling of automated sequencer traces using phred. I. Accuracy assessment. Genome Res. 8(3), 175-185.

20. Faoro, H.; Alves, A.C.; Souza, E.M.; Rigo, L.U.; Cruz, L.M.; Al-Janabi, S.M.; Monteiro, R.A.; Baura, V.A.; Pedrosa, F.O. (2010). Influence of soil characteristics on the diversity of bacteria in the Southern Brazilian Atlantic Forest. Appl. Environ. Microbiol. 76(14), 4744-4749.

21. Fey, A.; Conrad, R. (2000). Effect of temperature on carbon and electron flow and on the archaeal community in methanogenic rice field soil. Appl. Environ. Microbiol. 66(11), 4790-4797.

22. Fierer, N.; Schimel, J.P.; Holden, P.A. (2003). Variations in microbial community composition through two soil depth profiles. Soil Biol. Biochem. 35(1), 167-176. 
23. Galand, P.E.; Fritze, H.; Conrad, R.; Yrjälä, K. (2005). Pathways for methanogenesis and diversity of methanogenic archaea in three boreal peatland ecosystems. Appl. Environ. Microbiol. 71(4), 2195-2198.

24. Galand, P.E.; Saarnio, S.; Fritze, H.; Yrjälä, K. (2002). Depth related diversity of methanogen Archaea in Finnish oligotrophic fen. FEMS Microbiol. Ecol. 42(3), 441-449.

25. Gordon, D.; Abajian, C.; Green P. (1998). Consed: a graphical tool for sequence finishing, Genome Res. 8(3), 195-202.

26. Green, P. (1994). PHRAP documentation. Available at: http://www.phrap.org.

27. Hartman, W.H.; Richardson, C.J.; Vilgalys, R.; Bruland, G.L. (2008). Environmental and anthropogenic controls over bacterial communities in wetland soils. Proc. Natl. Acad. Sci. U. S. A. 105(46), 17842-17847.

28. Horn, M.A.; Matthies, C.; Küsel, K.; Schramm, A.; Drake, H.L. (2003). Hydrogenotrophic methanogenesis by moderately acid-tolerant methanogens of a methane-emitting acidic peat. Appl. Environ. Microbiol. 69(1), 74-83.

29. Janssen, P.H. (2006). Identifying the dominant soil bacterial taxa in libraries of 16S rRNA and 16S rRNA genes. Appl. Environ. Microbiol. 72(3), 1719-1728

30. Juottonen, H.; Tuittila, E.S.; Juutinen, S.; Fritze, H.; Yrjälä, K. (2008). Seasonality of rDNA- and rRNA-derived archaeal communities and methanogenic potential in a boreal mire. ISME J. 2(11), 1157-1168.

31. Kemnitz, D.; Chin, K.J.; Bodelier, P.; Conrad R. (2004). Community analysis of methanogenic archaea within a riparian flooding gradient. Environ. Microbiol. 6(5), 449-461.

32. Kielak, A.; Pijl, A.S.; van Veen, J.A.; Kowalchuk, G.A. (2008) Differences in vegetation composition and plant species identity lead to only minor changes in soil-borne microbial communities in a former arable field. FEMS Microbiol. Ecol. 63(3), 372-382.

33. Kindt, R.; Coe, R. (2005). Tree Diversity Analysis. A Manual and Software for Common Statistical Methods and Biodiversity Studies. World Agroforestry Centre. ICRAF, Nairobi.

34. Krüger, M.; Frenzel, P.; Kemnitz, D.; Conrad, R. (2005). Activity, structure and dynamics of the methanogenic archaeal community in a flooded Italian rice field. FEMS Microbiol. Ecol. 51(3), 323-331.

35. Lansdown, J.; Quay, P.; King S. (1992). CH4 production via CO2 reduction in a temperate bog: A source of 13C-depIeted $\mathrm{CH} 4$. Geochim. Cosmochim. Acta. 56(9), 3493-3503.

36. Lloyd, K.G.; Lapham, L.; Teske A. (2006) An anaerobic methaneoxidizing community of ANME-1b archaea in hypersaline Gulf of Mexico sediments. Appl. Environ. Microbiol. 72(11), 7218-7230.

37. Moyer, C.L.; Tiedje, J.M.; Dobbs, F.C.; Karl, D.M. (1998). Diversity of deep-sea hydrothermal vent Archaea from Loihi Seamount, Hawaii. Deep Sea Res. II. 45(1), 303-317.

38. Myers, N.; Mittermeier, R.A.; Mittermeier, C.G.; Fonseca, G.A.; Kent, J.
(2000). Biodiversity hotspots for conservation priorities. Nature. 403(6772), 853-858.

39. Nunoura, T.; Soffientino, B.; Blazejak, A.; Kakuta, J.; Oida, H.; Schippers, A.; Takai, K. (2009). Subseafloor microbial communities associated with rapid turbidite deposition in the Gulf of Mexico continental slope (IODP Expedition 308). FEMS Microbiol. Ecol. 69(3), 410-424.

40. Oline, D.K.; Schmidt, S.K.; Grant, M.C. (2006). Biogeography and landscape-scale diversity of the dominant Crenarchaeota of soil. Microb. Ecol. 52(3), 480-490.

41. Posada, D.; Crandall, K.A. (1998). MODELTEST: testing the model of DNA substitution. Bioinformatics. 14(9), 817-818.

42. R Development Core Team. (2007). R: A Language and Environment for Statistical Computing. R Foundation for Statistical Computing: Vienna, Austria. http://www.R-project.org.

43. Richardson, C.J.; Tilton, D.L.; Kadlec, J.A.; Chamie, J.P.M.; Wentz, W.A. (1978). Nutrient dynamics of northern wetland ecosystems. In: Good, R.E.; Whigham, D.F.; Simpson, R.L. (eds.) Freshwater Wetlands: Ecological Processes and Management Potential. Academic Press, New York, USA. p. 217-241.

44. Rieley, J.O.; Wust, R.A.J.; Jauhiainen, J.; Page, S.E.; Ritzema, H.; Wosten, H.; Hooijer, A.; Siegert, F.; Limin, S.; Vasander, H.; Stahlhut, M. (2008). Tropical Peatlands: Carbon stores, carbon gas emissions and contribution to climate change processes. In: Strack, M. Peatlands and climate change. Peat Society, Calgary, Canada. p.44-70.

45. Sakai, S.; Imachi, H.; Sekiguchi, Y.; Ohashi, A.; Harada, H.; Kamagata Y. (2007). Isolation of key methanogens for global methane emission from rice paddy fields: a novel isolate affiliated with the clone cluster rice cluster I. Appl. Environ. Microbiol. 73(13), 4326-4331.

46. Schloss, P. D.; Larget, B.R.; Handelsman J. (2004). Integration of microbial ecology and statistics: a test to compare gene libraries. Appl. Environ. Microbiol. 70(9), 5485-5492.

47. Schloss, P.D.; Westcott, S.L.; Ryabin, T.; Hall, J.R.; Hartmann, M.; Hollister, E.B.; Lesniewski, R.A.; Oakley, B.B.; Parks, D.H.; Robinson, C.J.; Sahl J.W.; Stres, B.; Thallinger, G.G.; Horn, D.J.V.; Weber, C.F. (2009). Introducing mothur: open-source, platform-independent, community-supported software for describing and comparing microbial communities. Appl. Environ. Microbiol. 75(23), 7537-7541.

48. Sliwinski, M.K.; Goodman, R.M. (2004). Comparison of crenarchaeal consortia inhabiting the rhizosphere of diverse terrestrial plants with those in bulk soil in native environments. Appl. Environ. Microbiol. 70(3), 1821-1826.

49. Smit, E.; Leeflang, P.; Gommans, S.; van den Broek, J.; van Mil, S.; Wernars, K. (2001). Diversity and seasonal fluctuations of the dominant members of the bacterial soil community in a wheat field as determined by cultivation and molecular methods. Appl. Environ. Microbiol. 67(5), 
2284-2291.

50. Steinberg, L. M.; Regan, J. M. (2008). Phylogenetic comparison of the methanogenic communities from an acidic, oligotrophic fen and an anaerobic digester treating municipal wastewater sludge. Appl. Environ. Microbiol. 74(21), 6663-6671.

51. Suzuki, M. T.; Giovannoni, S. J. (1996). Bias caused by template annealing in the amplification of mixtures of 16S rRNA genes by PCR. Appl. Environ. Microbiol. 62(2), 625-630.

52. Swofford, D. L. (2000). PAUP*: Phylogenetic Analysis Using Parsimony (and Other Methods), Version 4. Sinauer Associates: Sunderland, MA.

53. Tamura, K.; Dudley, J.; Nei, M.; Kumar, S. (2007). MEGA4: Molecular Evolutionary Genetics Analysis (MEGA) software, Version 4. Mol. Biol.
Evol. 24(8), 1596-1599.

54. Teske, A. (2006). Microbial Communities of Deep Marine Subsurface Sediments: Molecular and Cultivation Surveys. Geomicrobiol. J. 23(6), 357-368.

55. Valladares, G. S. (2003). Caracterização de Organossolos, auxílio à sua classificação. Seropédica, Brazil, 129p. (PhD thesis. UFRJ).

56. Weber, S. (2001). Methanogenic populations involved in the degradation of rice straw in anoxic paddy soil. FEMS Microbiol. Ecol. 38(1), 11-20.

57. Yashiro, Y.; Sakai, S.; Ehara, M.; Miyazaki, M.; Yamaguchi, T.; Imachi H. (2011). Methanoregula formicica sp. nov., a methane-producing archaeon isolated from methanogenic sludge. Int. J. Syst. Evol. Microbiol. 61(1), 53-59. 